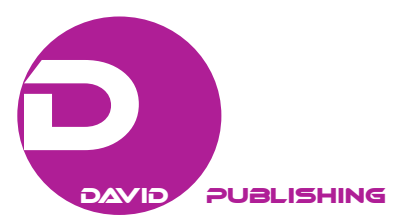

\title{
Covered Bonds in Europe: Issuing and Markets
}

\author{
Kamil Liberadzki \\ Warsaw School of Economics, Warszawa, Poland
}

\begin{abstract}
The development of covered bonds of the pfandbrief type has last for more than 200 years in Europe. Covered bonds expanded further as a competitive capital markets instrument and proved to be the most resilient wholesale term-funding instrument for credit institutions during the last financial crisis. Nowadays, their strategic importance as a long-term funding tool has been clearly recognised at the global level. Europe, Canada, Australia, and New Zealand have established covered bond frameworks and will continue to be the backbone of the market. Brazil, Chile, India, Japan, Morocco, Peru, Singapore, and South Korea are in the process of adopting covered bond legislation or are investigating the potential introduction of this funding tool. Turkey has had dedicated covered bond legislation since 2011. The aim of this research is to present and compare the existing covered bonds structuring models. Here an important research question arises - in which aspect any of the considered models may get close to asset backed securities (ABS) structure? There is no common covered bonds legal regime throughout the EU. Instead, each EU member state relies upon its own regulations. Therefore, five representative covered bonds issuance schemes are presented in this article. Another research objective was to observe covered bonds prices evolution just prior to and after the outbreak of financial crisis. The last part of the article contains an analysis of post-crisis cover bond market and European Central Bank policy with respect to it. The covered bonds almost entirely outstand the financial market turmoil since mid-2007. However, covered bonds spread analysis presented in the paper proves that the European Central Bank (ECB) is a main player supporting covered bond secondary.
\end{abstract}

Keywords: covered bonds, pfandbriefe, mortgage financing, asset backed securities (ABS), securities market programme, cover bonds purchase programme

\section{Introduction}

The recent financial crisis revealed obvious weaknesses of US mortgages financing model based on securitization concept (using asset backed securities [ABS] structure), which up to September 15, 2008 had been regarded as probably the ultimate one. There is an alternative for the securitization-based model though the covered bonds.

Despite the fact that covered bonds proved their superiority over ABS during the crisis, these instruments seem to be somehow undepreciated - at least outside European Union. However, even in Europe still, there is not a single definition of covered bonds, not mentioning a common standard and legal basis for them. This paper in sections 1 and 2 refers to legal aspects of covered bonds according to different countries' legal systems, classifies covered bonds structures, and compares them with ABS concept. Following sections are devoted to

Kamil Liberadzki, Ph.D., junior professor, Institute of Finance, Warsaw School of Economics, Warsaw, Poland.

Correspondence concerning this article should be addressed to Kamil Liberadzki, Instytut Finansów Szkoły Głównej Handlowej, Madalińskiego 6/8 Street, 02-513 Warszawa, Poland. E-mail: kliber@sgh.waw.pl. 
analysis concerning the market developments just prior to and after the financial crisis. The worldwide financial turmoil was definitely caused by mortgages market collapse, however, European covered bonds seemed to remain intact, which is shown in section 4 . Covered bonds market plays currently another crucial role for the economy: It is among main transmission channels for the European Central Bank monetary impulses. Section 5 presents the application of covered bond markets by the euro-zone monetary authorities in pursuing their targets and the impact of the selected monetary operations on the covered bonds price evolution. There has not been obviously much literature combining pure legal aspects of covered bonds with a strictly economic analysis, so this article should somehow fill in this gap.

In its basic form, a covered bond is a debt instrument that pays a fixed interest rate (the coupon payment), with principal repaid at maturity. A key feature of these bonds is that the payments are collateralized by a pool of specific assets. The pool of collateral backing a covered bond is required to be at least equal in value to the principal outstanding of the issued bonds (Rosen, 2008). In Europe, it is common to refer to "covered bonds" or "mortgage bonds" when referring to different types of bonds backed by mortgage assets or public sector loans. Despite their long tradition, there is still no common definition. Plans for a draft EU Directive governing the issuance of securities guaranteed by a mortgage or other assets were abandoned by the European Commission following the publication in 1985 of the White Paper on the Internal Market, which put forward the principle of mutual recognition as an alternative to harmonization (Fabozzi, 2004). However, recently the European Banking Authority (EBA) is due to come up with a comparative overview on covered bonds which will outline that the areas it believes are in need of harmonisation across Europe (Varriale, 2014). The European Commission wants to harmonise the covered bond market and will assess its preferential regulatory treatment. As harmonisation of national laws will be almost impossible, collateral transparency standards could be harmonised and collateral eligibility could be more precisely defined.

After over two centuries of life and use in the European debt markets, where covered bonds have played an increasingly important role in the financing of both mortgages and public sector credit, the concept of a covered bond market is being widely evaluated by other countries. This has been driven by a number of factors including the limited availability of long-term unsecured funding, the increased long-term liquidity requirements coming from Basel III rules (liquidity buffers), and the fact that they are senior to other instruments and they can hold their value in times of volatility (International Financial Law Review, 2013a). Europe, Canada, Australia, and New Zealand have established covered bond frameworks and will continue to be the backbone of the market. Brazil, Chile, India, Japan, Morocco, Peru, Singapore, and South Korea are in the process of adopting covered bond legislation or are investigating the potential introduction of this funding tool (International Financial Law Review, 2013b).

Morocco is now in the front line to pass a draft law by late 2013. The law is currently under review. It would be Africa's first covered bond regime. Morocco's covered bond legislation is mostly based on benchmarks drawn from the German pfandbrief legislation (on-balance sheet framework) in terms of specific supervision, monitoring of the cover pool by an independent comptroller, and implementation of prudential regulations on the cover pool (International Financial Law Review, 2013a). Under Morocco's covered bond regime, only banks can issue covered bonds. The total amount of covered bonds must not exceed $20 \%$ of the total assets of the bank. The net present value of the cover portfolio must be, at any time, more than $105 \%$ of the net present value of the covered bonds. Selected loans for the cover portfolio must have a remaining capital under $80 \%$ of the value of the asset (International Financial Law Review, 2013c). 
Turkey has had dedicated covered bond legislation since 2011. Turkey has adopted a different approach to the other new legislative frameworks. Legislation has focused on two different on-balance sheet covered bond classes: the traditional mortgage covered bonds and small and medium enterprises (SME) covered bonds (covered bonds backed by loans to SMEs). It is the first country in the world to have a specific legislation for SME covered bonds (International Financial Law Review, 2013a).

\section{Covered Bonds Issuance Schemes}

Covered bonds offer an alternative to securitisation as a means to finance mortgages (Rosen, 2008). They are subject to special governing legislation. These bonds are "covered" or backed by underlying asset pools, equating to at least the same nominal amount of the issue. The assets contained within these pools must be recorded into a cover register, maintained by the mortgage bank, to ensure that these are easily identifiable. In this regard, covered bonds, such as pfandbriefe, are considered highly secure. In the event of the issuing mortgage bank becoming insolvent, the creditors would receive a preferential claim over the assets in the cover pool, which is there solely to protect them. Covered bonds offer high safety while at the same time granting the investor an enhanced yield in comparison to government bonds (Batten, Fetherston, \& Szilagyi, 2004). Issuance of the covered bonds is limited only to issuers of a certain type: credit institutions. It does not mean, however, that national models may not vary with regard to the model of an issuance. In fact, there may be distinguished five models of covered bonds issuance. Covered bonds may be issued by:

(1) specialized funding institute;

(2) specialized credit institution;

(3) universal credit institution with special license;

(4) universal credit institution without any special license;

(5) special purpose vehicle model.

\section{Specialized Funding Institute}

This model requires the parent bank to establish and manage a completely specialized funding institute. Parent bank transfers the cover pool eligible assets on the institute, whose only function is to hold them. The funding institute must also possess the legal status of a credit institution. This model allows to separate the issuer and the cover pool assets from the bank (the originator of the issue) for the insolvency purposes.

Income received by the specialized funding institute (the issuer) on the cover pool assets is used to satisfy payment of principle and interest to investors. In turn, the issuer would transfer on the parent bank sources paid by covered bonds investors, as a remuneration for acquired cover pool assets.

This model, relatively similar to process of securitization, is used in France, Ireland, and Norway. This model of covered bond issuance is the one most similar to securitization, but, of course, it has a unique feature of claim against the issuer.

Of course, this basic model may be a subject to further developments: The most common one being participation of many banks is one issuance by the covered bonds issuer. Then, mortgage loans from many banks (originators of the issuance) are pooled for the purposes of the issuance: transferred to the covered bonds issuer. It may also be the case that two types of banks participate in a single transferred mortgage loan: a leading bank and a syndication bank. In that model, called syndication, a leading bank lends money and syndication banks take part in the risk by means of risk subparticipation. If syndication bank aims to issue covered bonds based on their risk syndication, it has to participate in the claim and in the mortgage (Figure 1). 


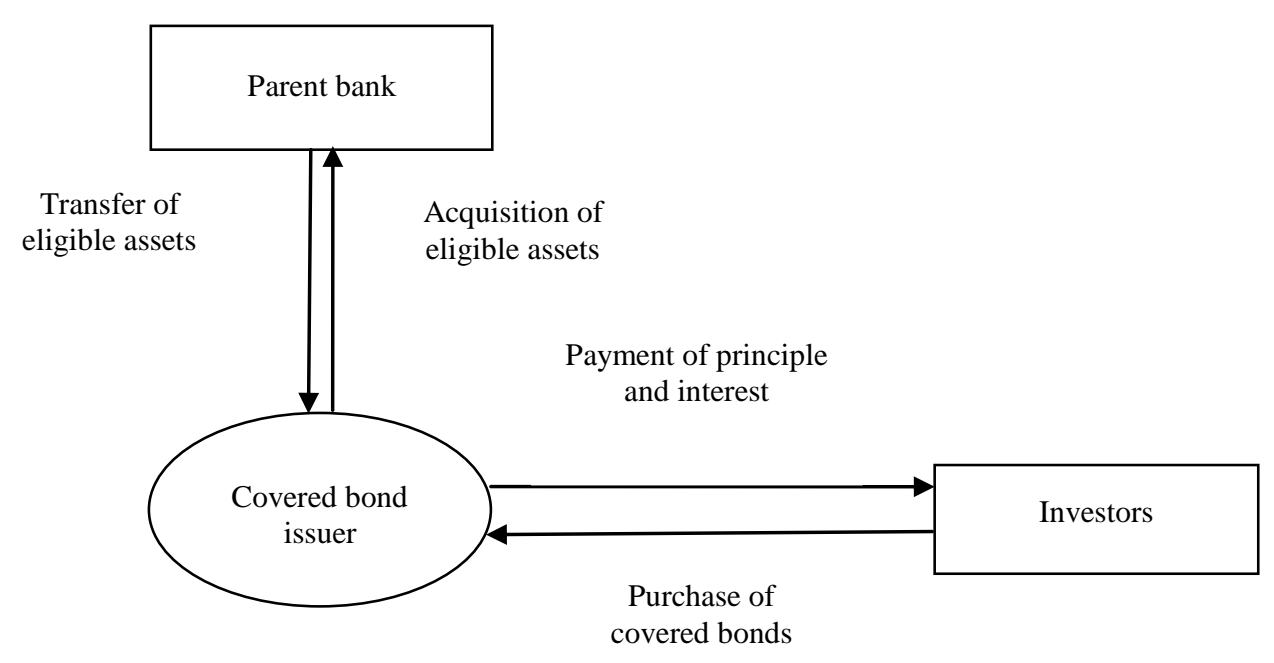

Figure 1. Issuance by specialized funding institute. Source: Schuster, Engelhard, Kaelberer, and Petersen (2012).

\section{Specialized Credit Institution by Law}

In this model, the issuer is not only required to possess the legal status of a credit institution, but also to be a credit institution specialized in mortgage loans or public-sector loans. This means that universal banks cannot be the covered bonds issuer. This very issuance model does not require the participation of any specialised funding institute and therefore, no asset transfer. The issuer simply issues the covered bonds, which are covered by assets segregated from his other estate for the purpose of the insolvency proceeding. This model applies to Denmark, Hungary, Luxemburg, and Poland (Figure 2).

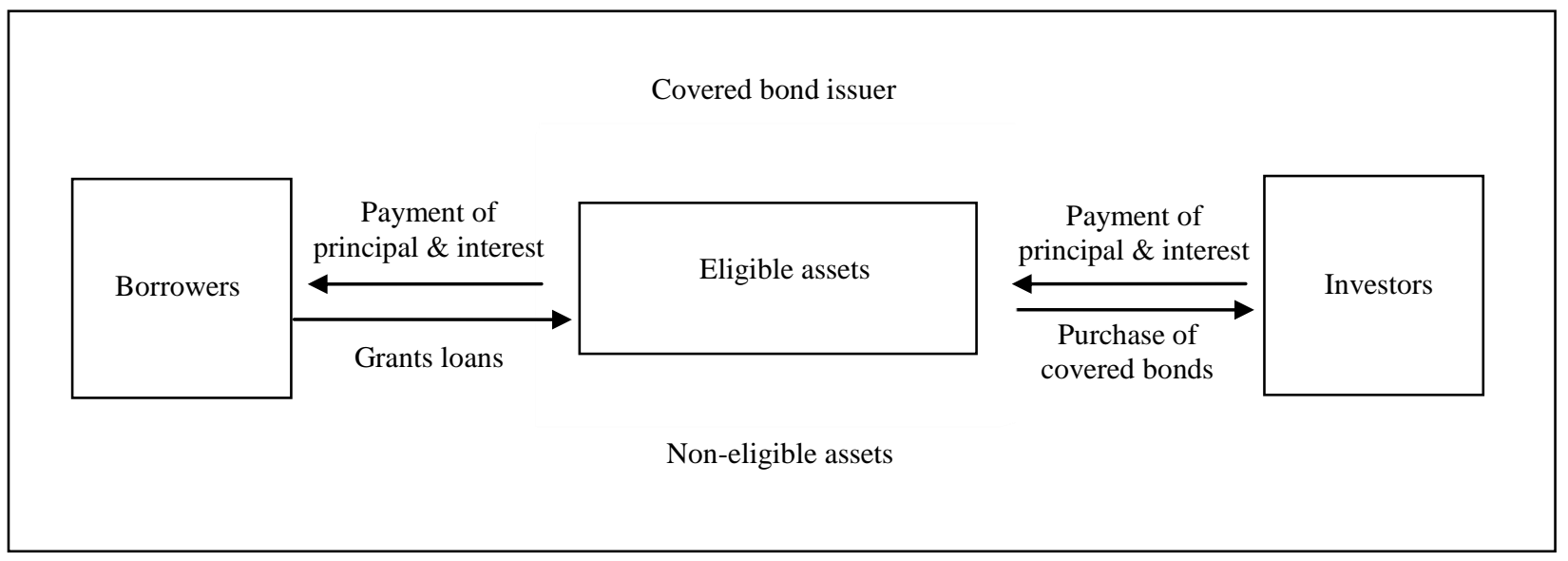

Figure 2. Issuance by “mortgage bank”. Source: Schuster et al. (2012).

\section{Universal Credit Institution With Special License}

The most common model allows a universal credit institution to issue a covered bond, provided that it has been granted a special license for this purpose. The license is typically granted by national financial regulator. As universal bank, the issuer's assets will comprise not only of cover pool eligible assets, but also of the non-eligible ones. Therefore, strict eligibility criteria must apply to cover pool assets in order to ensure safety of the bondholders. Cover pool assets are segregated from other issuers' estate in case of insolvency. This 
model applies to Austria, Belgium, Cyprus, Finland, Germany, Greece, Latvia, Sweden, Iceland, and Russia. The scheme of covered bonds issuance is similar to the one presented in Figure 2.

\section{Universal Credit Institution Without Any Special License}

More liberal approach may be found in Bulgaria, Czech Republic, Lithuania, Portugal, Romania, Spain, and Slovakia, where the universal credit institution is not required to obtain any special license for the purpose of the covered bonds issuance. The scheme of covered bonds issuance corresponds to one presented in Figure 2 and Figure 3.

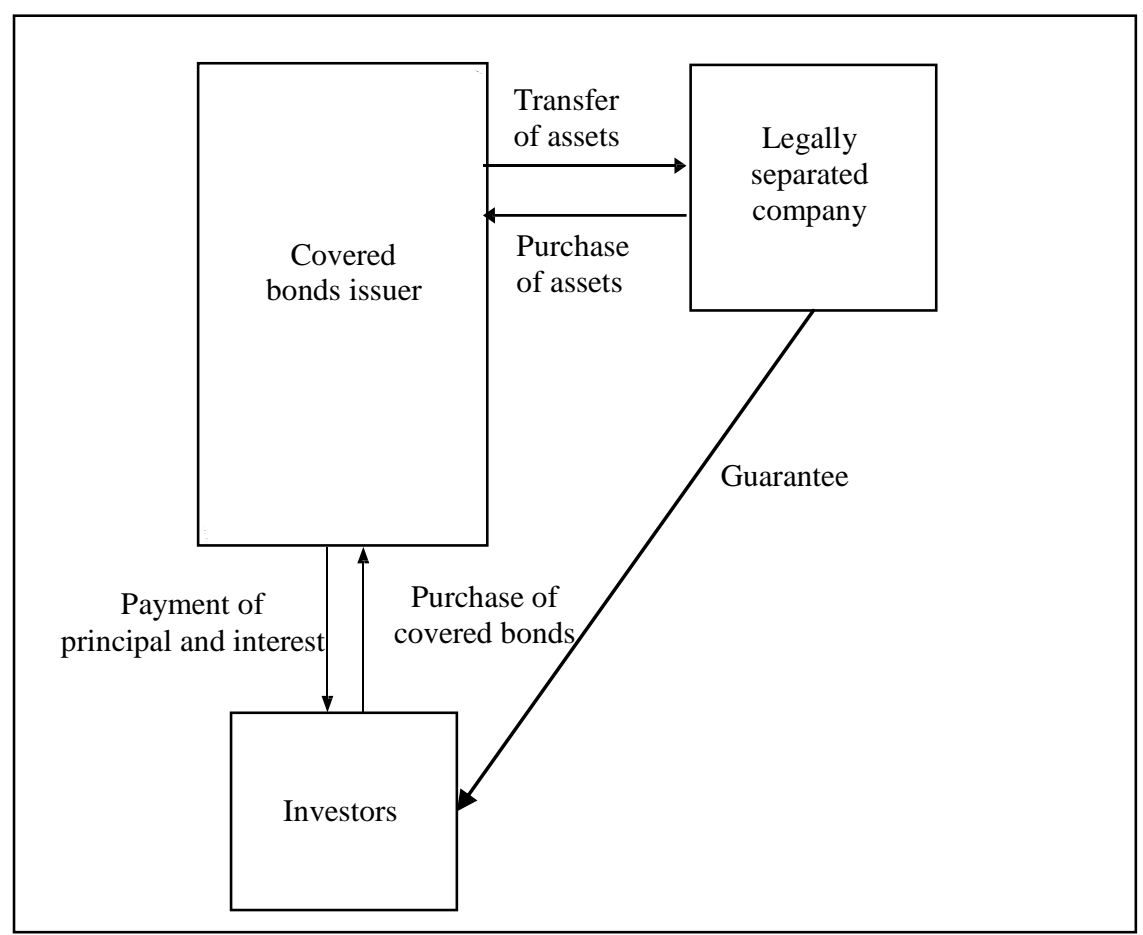

Figure 3. Special purpose vehicle in the issuance process. Source: Schuster et al. (2012).

Besides, in some jurisdictions, it is also necessary to use a special purpose vehicle (SPV) entity in the process of covered bonds issuance for the purpose of cover pool assets segregation (ring-fencing) from other assets of the issuer. SPV is not the issuer - the bank is - and it acts only as guarantor for the bondholders: It guarantees payment of principal and interest. Therefore, there is no need that it should possess the legal status of financial institution.

\section{Covered Bonds vs. ABS and Senior Unsecured Bonds}

While covered bonds are often regarded as similar to ABS and mortgage-backed securities (MBS), many noteworthy differences exist between them. First and foremost, covered bonds are dual recourse instruments issued by a financial institution (or offering recourse to a financial institution) equipped with a priority recourse to a cover pool of bonds collateral. Dual recourse means that investors have a claim against the issuer and in the event of his failure they also have a priority claim on the covered pool (ECB, 2008). A claim on the issuer is of key importance when comparing covered bonds with ABS, as it results in absence of credit risk transfer. In the case of ABS or MBS, the assets are segregated from any other assets and are usually off balance sheet and placed in an SPV. For ABS/MBS, in the event of insufficient proceeds from the pool assets to cover the claim, 
holders have no recourse above and beyond the collateral contained within the pools and the original ABS/MBS structure (Fabozzi \& Choudhry, 2004). Therefore, one could describe covered bonds as a dual recourse instrument, combining the advantages of a senior unsecured bond (claim against the issuer) and of an ABS (claim against the assets backing the security). Another difference is on a regulatory field: Being under regulation, covered bonds issuances are subject to financial supervision, while securitization activity has been mostly beyond the directly regulated segments of the financial system (ECB, 2008).

On one hand, it is interesting to note that the development of covered bonds of the pfandbrief type has been around for more than 200 years in Europe. On the other hand, issuance of ABS bonds is a relatively recent phenomenon and has been brought about by innovation in the financial sector (Batten et al., 2004).

\section{Coupon and Maturity}

When ABS usually has floating rates coupon, covered bonds are fixed-income instruments with "bullet" maturities. Bullet bonds are non-callable, which has an impact on the bonds coupon. Bullet bonds pay relatively low rate of interest, reflecting issuers' exposure to interest-rate risk, which cannot be mitigated due to absence of a call option. Bullet bonds are also referred to as noncallable-for-life issues (Fabozzi, 2005).

As regards the maturity, covered bonds were originally (i.e., to mid-2007) issued with five to 10 years' maturity. Financial turmoil resulted in shortening of this period, as 2007-2008 issuances usually had only two to three years' maturity (ECB, 2008). Next years brought the dominance of five to seven years' maturity and eventually an evident trend to issue covered bonds with maturity longer than 10 years (ECB, 2010).

\section{Currency}

It is quite obvious that most covered bonds issues are denominated in EUR. However, issues from other currency regions also play a role.

Each of these markets has its own features: USD-denominated issuances are typically of a jumbo size (while the size of European ones has dropped), have shorter maturities and higher rankings. Issuers from Canada, Australia, and Norway are key players on the USD market. Besides, only the biggest European banks have access to this market. The majority of investors in USD-denominated covered bonds are Qualified Institutional Buyers (QIBs) based in U.S., so the most common type of covered bonds issuance is to offer them under Rule 144A. It is believed that prospective issuers from non-European countries, where legislation on cover bonds is in progress, will choose the USD market rather than the EUR market (Caris \& Barua, 2013).

The pound sterling (GBP) covered bonds market is still in nascent stage, but is growing rapidly. UK issuers, who supply $84 \%$ of outstanding public issuances, largely dominate the pound sterling (GBP) market. It should be noted that also issuers not domiciled in UK (Australia, Germany, France, and Sweden) choose the GBP market to broaden their investor base, use swaps to optimize the funding mix, reduce the supply in Euros, and finally hedge foreign-currency denominated assets in the cover pool (King, 2013).

\section{Rationale for Covered Bonds Issuance}

\section{Refinancing of Loans}

The most typical and common goal of covered bonds issuance is, of course, refinancing of mortgage loans, both for financing private and commercial property. While real estate financing is the core element of covered bonds business, its second largest segment is public sector finance. Despite the limits laid on long-term financing, banks still provide significant financing for governments, semi-sovereign bodies (regions, 
municipalities, and cities), and public sector institutions. This significance decreases, as semi-sovereign bodies expand their access to financial markets, once exclusive for governments. Recently, covered bonds are issued on a regular basis to find public sector lending only in a few European countries: Austria, France, Germany, Luxembourg, Norway, Spain, and UK (Grossmann \& Stöcker, 2013).

Besides, one may take to account the tiny role that covered bonds play on a specialised finance field such as aircraft and shipping finance. These niche segments of financial market have their unique features and also require unique financing. Nowadays, banks tend to pull out of shipping finance, while many financial institutions find aircraft finance more and more attractive. Shipping or aircraft loans are eligible for cover pool only in few countries: Denmark, Greece, Luxembourg, and Germany (Schulz, 2013). First issuance of German pfandbriefe backed by aircraft loans took place in 2012 (Grossmann \& Stöcker, 2013).

\section{Lower Cost of Funding}

As it was mentioned earlier, covered bonds may be considered as an alternative to securitisation. The key difference is the absence of credit risk transfer, as the issuer has to hold capital against the risk of losses. Absence of this risk results in absence of risk premium for the covered bond holders, which allows the issuer of the covered bonds to obtain funding cheaper than by securitisation. As a result of double recourse, covered bonds typically obtain higher credit rating than the issuers rating. That is why the main rationale for covered bonds issuance is to access cheaper funding for longer maturities, when compared with ABSs and senior unsecured bonds.

\section{Covered Bonds as Collateral}

Another useful feature of covered bonds is their ability to constitute a collateral for loans from central banks. Such loans - a usual way to supply the banking system with liquidity - are made against high-quality collateral, specified in a Eurosystem's single list of eligible collateral. Dual recourse character of cover bonds enabled them to be put on that list, for they limit the risk of losses to the central banks. Therefore, covered bonds contribute to an effective implementation of monetary policy. What's more, ECB used to accept "retained" covered bonds (that is, self-issued by banks) as collateral, which made the bank's balance sheets assets eligible for liquidity operations of ECB. However, this approach recently shifts towards a more conservative one, limiting the use of retained covered bonds as repo eligible collateral (Will \& King, 2013).

\section{Risk Management Incentives}

In securitisation process, credit risk is transferred from the originator (issuer) and ABS holders may satisfy their claim only from the assets backing the bonds. Unregulated, this process may lead (and, in fact, it had led) to serious negligence on the field of credit risk evaluation and monitoring. In case of a cover bonds issuance, the dual recourse mechanism and non-transferring the cover pool assets outside from the issuer's balance sheet ensures that the credit institution sees to its risk management.

\section{Covered Bonds Market in the EU}

\section{Rapid Growth (2003-2007)}

The EU covered market bond experienced significant growth between 2003 and 2007, increasing by 38\%. During that period, traditional primary issuers of covered bonds, i.e., German and Danish credit institutions, were followed by banks from Spain, France, and UK that also came up with substantial issuances. The main factors of rapid growth were need to finance fast growth of the mortgage business in the Central and Eastern 
Europe (CEE) countries, which provided a constant increase of the potential asset pool, and investor-friendly legislation, which made investors base very broad. In a matter of credit rating, covered bonds filled the gap between the government bonds and other issuers. Financial institutions are main group of covered bonds investors, though in some countries even retail investors do invest in covered bonds. At the end of 2006, USD-denominated covered bonds were introduced, as a tool of diversification of the financial exposure through different currencies.

The secondary market for covered bonds is much less liquid than government bond market, but also much more liquid than ABS market (especially when considering the jumbo covered bonds).

\section{Market Turmoil Since Mid-2007}

Even being among the safest investments on the market (because of the dual-recourse mechanism), covered bonds could not have entirely understood the financial market turmoil since mid-2007, although it must be said that they performed much better than single-recourse instruments (ABSs, MBSs, or senior bank loans). Indeed, performance of mortgage-backed pfandbriefe, although not free from volatility, was better than performance of bonds issued by the governments of distressed EU countries (see Figure 4).

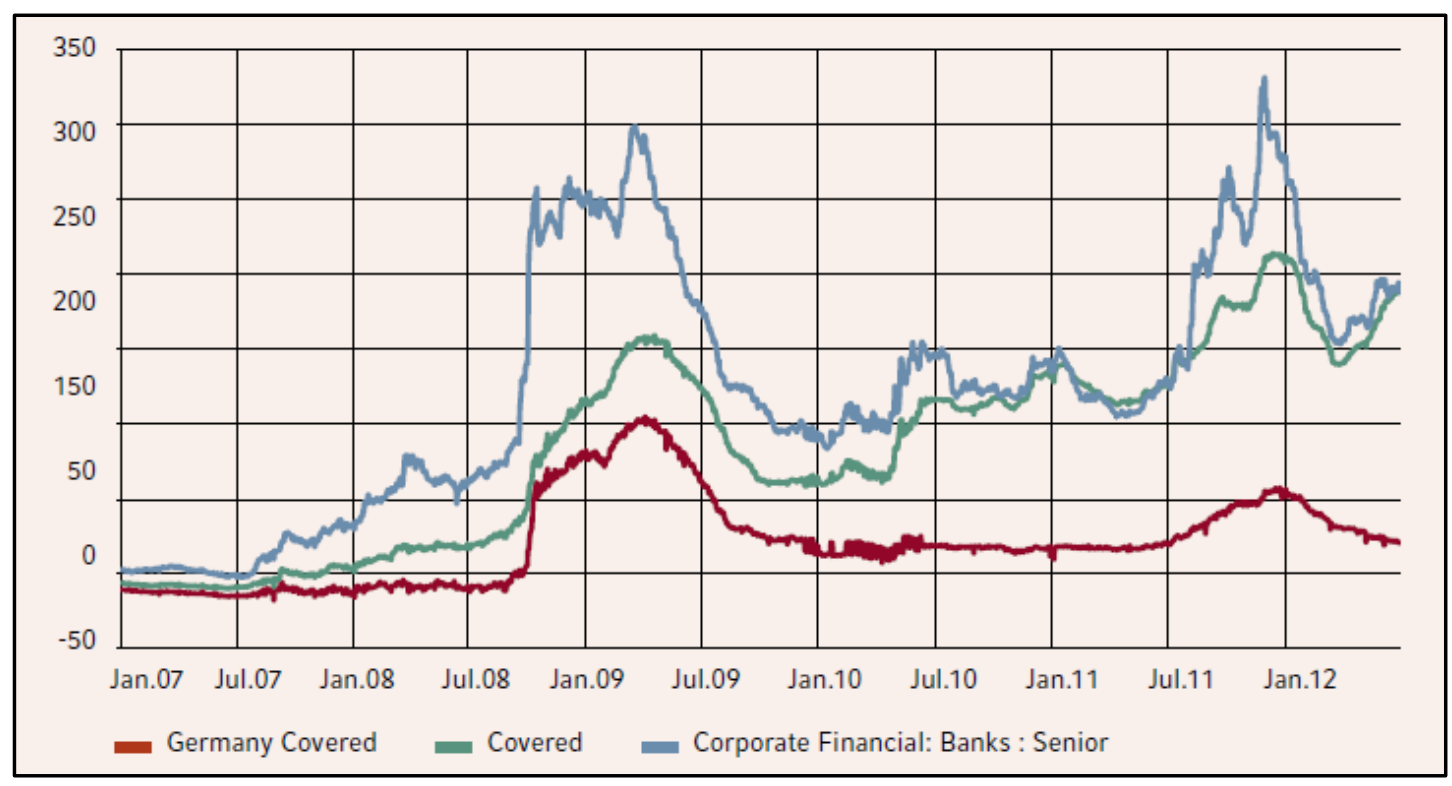

Figure 4. Performance of the mortgage pfandbriefe spreads against the government bonds. Source: Volk (2012).

Increased risk aversion resulted in a general widening of covered bonds swap spreads since August 2007. Still, this swap spread widening was not as significant as in case of senior financial debt. Mayor hit on covered bonds market took place on turmoil intensification of September 2008. Increased market volatility resulted in increased value at risk (VAR) in portfolios of market participants. This applied also to market makers, who play extraordinary role in the jumbo covered bonds market and whose risk could not be sufficiently mitigated because of hedging difficulties (arising from the extraordinary volatility). ${ }^{1}$ Primary market fell dramatically and the decline of new issuances was mostly seen in Germany, which lost its traditional dominant position on

\footnotetext{
1 The "jumbo" segment was developed in order to increase the liquidity of the covered bond market. Jumbo covered bonds were established in 1995 with the primary objective of broadening the investor base by attracting international investors. In this market segment, only "plain-vanilla" fixed rate bullet bonds in euro with a minimum issue size of $€ 1$ billion are issued and at least five market makers are required to quote each other bid/ask prices for ticket sizes of up to $€ 15$ million (ECB, 2008).
} 
the market in terms of the issuance. Another factor that led to increase of spreads was liquidity risk and S\&P 500 announcement of 2009 about upcoming amendments to the rating methodology, which caused some uncertainty on the market (ECB, 2010).

\section{ECB Covered Bonds Purchase Programs 2009-2013 and Their Impact on Price Development}

On 7th of May 2009, the ECB Governing Council announced that euro system would purchase covered bonds issued in the euro area up to a total value of EUR 60bn in order to revitalise the market (ECB, 2010). The very announcement resulted in first signs of the market recovery. The Cover Bonds Purchase Programme (CBPP1) started on July 2009 and brought increase to the primary market, significantly cutting down yield spreads (see Figure 5). Two weeks after the announcement of CBPP1 spreads tightened by around 10bp and the similar effect was observed in the two weeks following the start of covered bond purchase by ECB. CBPP1 reopened the primary market, bringing to the market around EUR 20bn in the month after its announcement and other EUR 16bn during the life of the programme (Schuller, 2013). It must be noted that CBPP also had impact in countries that were not covered by that programme (Denmark, Sweden, or UK). Yield spreads declined in a similar way also with regard to corporate bonds issued by banks, what may lead to conclusion that, because of the financial integration, developments on the covered bonds market may have impact on related markets (ECB, 2010).

On May 10, 2010, ECB announced its Securities Market Programme (SMP) which was aimed to influence financial markets in general. Programme started just four days after its announcement and brought quite opposite impact on spreads. Following the success of CBPP, ECB decided to start CBPP2. Decision was announced on 6th of October 2011, while program started on 11th of November 2011. The overall effect in the environment of spreads was a sharp difference between core Europe and distressed European countries, where primary market virtually ran dry (Schuller, 2013). Therefore, impact of the financial crisis is mostly seen on covered bonds issued in the weaker euro-zone countries: Spread of the iBoxx Covered Bond index against swaps widened significantly since 2007 to the end of 2011, while spread against swaps for iBoxx Covered Bonds Germany is much narrower (Volk, 2012). Simultaneously, pfandbrief yields have been consequently falling since 2008 (except for rise in first half of 2011), while yields for European covered bonds have performed in more variable manner.

December 2011 brought the announcement of ECB three years jumbo Longer-Term Refinancing Operations (LTROs) and settlement of its first tranche. As a result, number of covered bonds increased but spreads level remained stable. Second tranche was settled in March 2012, bringing tightening of spreads in the distressed European countries by $10 \mathrm{bp}$ and by $22 \mathrm{bp}$ in the non-distressed ones. This effect proved to be temporary as spreads started to widen since April 2012. What's more, LTROs are believed to have a longer and negative impact on the EUR-denominated covered bonds market and in fact to be accountable for decrease of public issuance in 2013. As LTRO is a three-year programme, it is also believed that by the end of 2015, public issuance of covered bonds will receive a stimulating impulse (Schuller, 2013). 


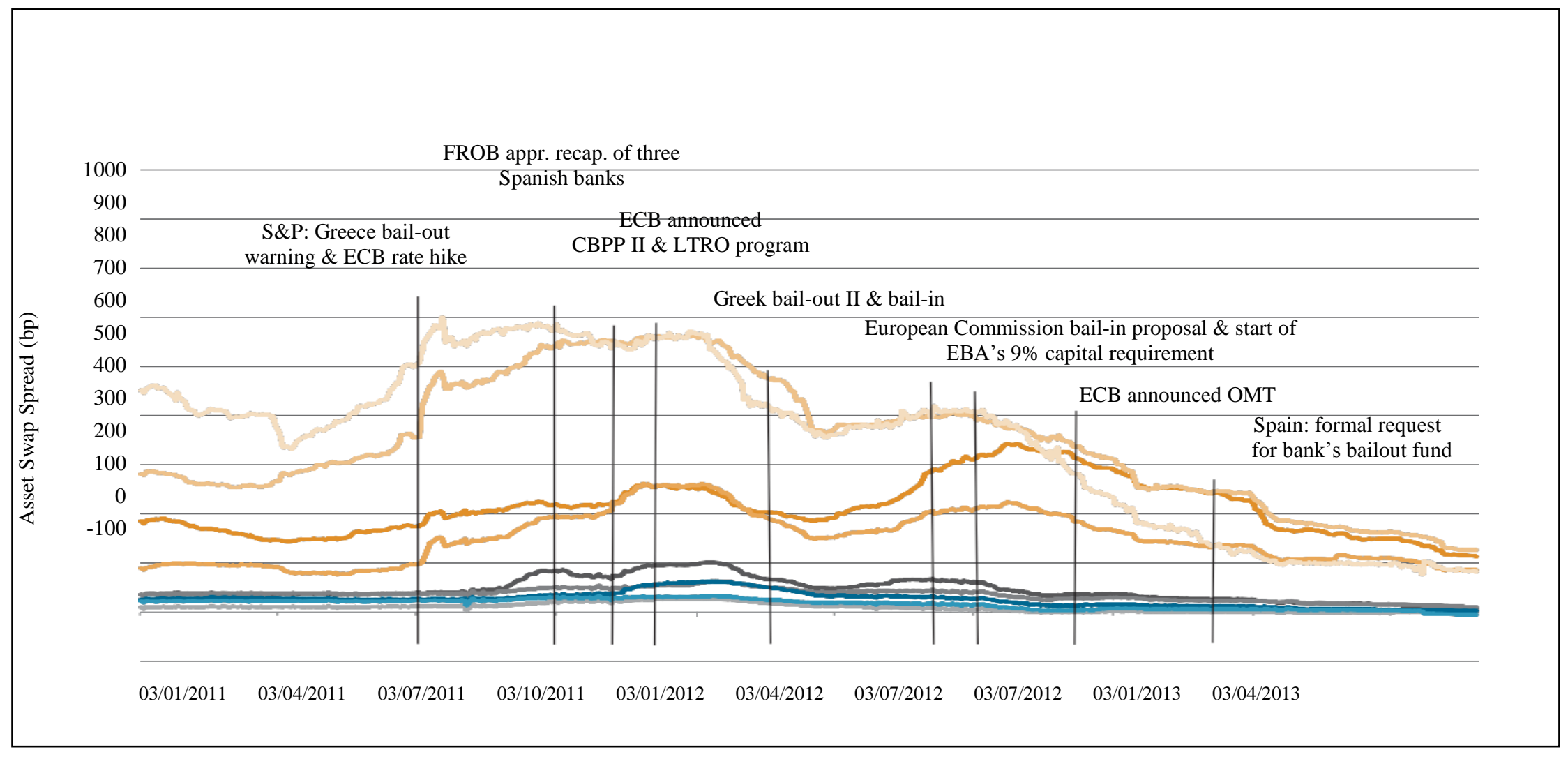

Figure 5. Historical covered bonds spreads and spread driver event. Source: Eichert and Hock (2013). 
In September 2013, ECB announced that unsuccessful SMP will be superseded by Outright Monetary Transactions (OMT) programme: purchase of government bonds in the secondary market, which had a great impact on spreads of covered bonds from the distressed European countries. A 20bp tightening of spreads followed right after announcement of OMT on the back of the subsequent tightening of government bonds of distressed countries. Strongest impact of OMT was yet to come: Announcement of the programme specifics and technical features at the beginning of September 2012 brought a spread tightening of more than $40 \mathrm{bp}$ (Schuller, 2013).

Going beyond an analyzed time period 2009-2013, it is worth to mention that on January 22, 2015, the European Central Bank launched its Expanded Asset Purchase Programme. It is a package consisting of the Third Covered Bond Purchase Programme (CBPP3), Asset-Backed Securities Purchase Programme (ABSPP), and Public Sector Purchase Programme (PSPP). The combined monthly purchases under the three programmes amount to $€ 60$ billion. They started in March 2015 with a duration of 18 months.

\section{Conclusions}

Before the recent financial crisis, there had been two alternative models for financing mortgages: the covered bonds and ABS model. The covered bonds almost entirely have outstood the financial market turmoil since mid-2007. This is the reason, why the concept of a covered bond market is being widely evaluated by other countries. However, during recent years, the divergence between covered bonds spreads of peripherial EMU countries against core EMU countries' covered bonds widened. Perhaps one of the solutions could be a legal convergence, i.e., common legal standard and regulation for covered bonds.

The covered bonds were intensively purchased on the market by the ECB within the CBPP thus resulting in the development of the primary and the secondary market. It is worth to stress that the main incentive for ECB action was not bringing a rescue for the covered bond market itself, but rather using covered bonds for transmitting ECB's monetary impulses into real economy.

\section{References}

Batten, J. A., Fetherston, T. A., \& Szilagyi, P. G. (2004). European fixed income markets: Money, bond, and interest rate derivatives. Chichester: John Wiley \& Sons.

Caris, A., \& Barua, R. (2003). The growing footprint of the USD covered bonds market. Brussels: European Mortgage Federation/European Covered Bond Council.

ECB. (2008). Covered bonds in the EU financial system. Retrieved from https://www.ecb.europa.eu/pub/pdf/other/coverbondsintheeufinancialsystem200812en_en.pdf?d35ddd08c3732a9acf044d100 $42 \mathrm{~d} 15 \mathrm{~d} 7$

ECB. (2010). European covered bonds. from https://www.ecb.europa.eu/home/search/html/index.en.html?q=financial\%20integration\%20in\%20europe

Eichert, F., \& Hock, U. (2013). Liquidity regulation, covered bonds and relative value. Brussels: European Mortgage Federation/European Covered Bond Council.

Fabozzi, F. J. (2005). Handbook of fixed-income securities. Hoboken: John Wiley \& Sons.

Fabozzi, F. J., \& Choudhry, M. (2004). The handbook of European fixed income securities. Hoboken: John Wiley \& Sons.

Grossmann, R., \& Stöcker, O. (2013). Overview of covered bonds. Brussels: European Mortgage Federation/European Covered Bond Council.

International Financial Law Review. (2013a). Covered bonds: The road to a global asset class. Retrieved from http://search.proquest.com/docview/1431637509?accountid=45618

International Financial Law Review. (2013b). Why covered bonds are a clear solution. Retrieved from http://search.proquest.com/docview/1431637081? accountid=45618 
International Financial Law Review. (2013c). Moroccan covered bonds: Africa's new generation of finance. Retrieved from http://search.proquest.com/docview/1431637362?accountid=45618

King, J. (2013). GBP-denominated covered bond market. Brussels: European Mortgage Federation/European Covered Bond Council.

Rosen, R. J. (2008). What are covered bonds? Retrieved from http://search.proquest.com/docview/214538615?accountid=45618

Schuller, M. (2013). ECB policy toolkit and covered bonds supply. Brussels: European Mortgage Federation/European Covered Bond Council.

Schulz, M. (2013). Long-term finance, long-term funding and the role of covered bonds. Brussels: European Mortgage Federation/European Covered Bond Council.

Schuster, G., Engelhard, F., Kaelberer, W., \& Petersen, K. I. (2012). EC directive on bank resolution and its effect on covered bonds (Conference presentation, Nykredit).

Varriale, G. (2014). SocGen: The future of covered bonds. Retrieved from http://www.iflr.com/Article/3350565/SocGen-the-future-of-covered-bonds.html

Volk, B. (2012). The pfandbriefe market 2011/2012. Retrieved from http://www.pfandbrief.de/cms/_internet.nsf/tindex/de_71.htm?OpenDocument\&0C575EA7E26D527EC1257A78002E6BD

Will, F., \& King, J. (2013). The repo treatment of covered bonds by central banks. Brussels: European Mortgage Federation/European Covered Bond Council. 